\title{
Inside Tokugawa Religion: Stars, Planets and the Calendar-as-method
}

\section{John Breen}

\begin{abstract}
The study of religion in early modern (Tokugawa) Japan has failed to keep pace with the study of religion in the periods that preceded and followed it. What has been lacking particularly are explorations of religious praxis. The present study proposes a novel approach to this subject with its critical focus on the Tokugawa calendar and its almanac commentaries. Calendars, and their multiple prescriptions for particular types of action and non-action, informed as they are by the cosmic wisdom of yin yang (onmyō) and five-phases-of-matter thinking ( gogyō shisō), offer unique insights into precisely the neglected field of religious practice. This study sets out to decode the calendar and explore the ways in which it determined religious practice in early modern Japan. It discloses the centrality of the worship of stellar kami.
\end{abstract}

\section{Introduction}

The study of religion in Tokugawa Japan has failed to keep pace with the study of religion in earlier, or indeed later periods, of Japanese history. A recent authoritative survey of the field by Janine Sawada pinpoints some interesting and important work on early modern pilgrimage but, for the rest, what passes for the study of Tokugawa religion is, in reality, Tokugawa intellectual history. ${ }^{1}$ So the trajectory set nearly half a century ago by Robert Bellah in his classic book Tokugawa religion continues with little interruption. ${ }^{2}$ As Sawada observes, Western scholars are only

1 Janine Sawada, 'Bibliography: religion and thought in early modern Japan', Early Modern Japan, spring 2002, pp. 72-85.

2 Robert Bellah, Tokugawa Religion: The Cultural Roots of Modern Japan, Glencoe: The Free Press, 1957. My comments here relate to the study of Tokugawa religion in non-Japanese scholarship. It is only recently that Japanese work on Tokugawa religion has liberated itself from the yoke of intellectual history.

John Breen, 'Inside Tokugawa Religion: Stars, Planets and the Calendar-asmethod', Culture and Cosmos Vol. 10 no 1 and 2, Spring/Summer and Autumn/Winter 2006, pp. 63-78.

www.CultureAndCosmos.com 
64 Inside Tokugawa religion: stars, planets and the calendar-as-method

now beginning to 'shake off a long-standing preference for doctrinal and classical textual studies'.

Since Sawada completed her survey in 2002, the study of Tokugawa religion - I speak here of non-Japanese scholarship - has been invigorated by the publication of two important books, Nam-Lin Hur's study of prayer and play in late Tokugawa Japan, and Helen Hardacre's book on religion and society in $19^{\text {th }}$ century Japan ${ }^{4}$ The importance of the former lies in its spatial focus on the single site of the Sensōji 浅草寺 temple in Asakusa, Tokyo; the latter's contribution lies in its critical analysis of gazetteers that highlight the diversity of religious practice on the ground in the Kanto region in late Tokugawa and early Meiji Japan.

Much remains to be done, however, and I would like to propose a new method that might serve to shed light on the 'religious praxis, especially personal, individual practices (as opposed to official ceremonies and rites)' that, as Sawada remarks, have so far been overlooked by scholars Japanese and non-Japanese. ${ }^{5}$ I contend that calendars and the almanac commentaries which began to proliferate in the mid- $17^{\text {th }}$ century constitute just such a method. Long before the end of the Tokugawa period, calendars began to spread throughout Japan. It has been argued that, by the $1840 \mathrm{~s}$, as many as 4.5 million calendars of different types were being printed and sold annually. Almanacs, though printed in much smaller numbers, were likewise accessible to the common man or woman; it is thought that every village head would have owned one. In the present, and very preliminary, study of the Tokugawa calendar and almanac, I propose that they offer vital insights into the dynamic complexity of popular religious practice in early modern Japan.

The Tokugawa calendar plotted the year and its pivotal moments as calendars everywhere and always do. It pinpointed solar and lunar eclipses, the spring and autumn equinoxes, the winter and summer solstices and the assorted holidays known generically as zassetsu 雑節.

3 Janine Sawada, 'Tokugawa religious history: studies in Western languages,' Early Modern Japan, spring (2002), p. 39.

4 Nam-Lin Hur, Prayer and Play in Late Tokugawa Japan: Asakusa Sensoji and Edo society, Cambridge, Mass.: Harvard Univesity Press, 2003. Helen Hardacre, Religion and Society in Nineteenth-Century Japan: A Study of the Southern Kanto Region, Using Late Edo and Early Meiji Gazeteers (Michigan Monograph Series in Japanese Studies), 2003.

5 Sawada, ‘Tokugawa religious history,' p. 40.

Culture and Cosmos 
But it is the calendar's additional, specialist knowledge which constitutes a mine of information on Tokugawa religious practice. The specialist knowledge to which I refer is none other than yin yang (Jap. onmyo 陰陽), the five phases (gogyō 五行) and the sexegenary cycle (jikkan $j \bar{u} n i s h i$ 十干十二支), and a plethora of other cosmic systems which they generated.

\section{The calendar}

Figure 1 shows a fragment of the first two pages of a calendar printed in Kyoto for the $4^{\text {th }}$ year of the Bunkyū 文久 era (1864). Occupying the centre of the right hand page are the benevolent female kami 神 Toshitokujin 歳徳神 and beneath her the malevolent male kami Konjin 金神, each accompanied by brief designations for the celestial spaces through which they will move during the course of the year. Illustrated above them are the nyoi hoju jewels 如意宝珠, which bring good fortune to all who set eyes upon them. Aligned either side, across the top of the first page, are eight kami collectively known as the hasshogun 八将軍, and the designations for the diverse directions they occupy. So, for example, there is the kami Taisai 大歳 who resides, says the caption, in the north; Daishōgun 大将軍, the kami in the west; and Daion 大陰 in the north west. ${ }^{6}$ All this spatial information is recapitulated in diagrammatic form at the bottom of the page. To the immediate left of the diagram are cursory notes on the whereabouts of the kami Dokushin 土公神, as he moves through the seasons, and a tabulation of long and short months.

This first page is typical in that it is dominated by spatial concerns, but the second and, indeed, all subsequent pages of the calendar plot the passage of Tokugawa time and, as they do, they encode its cosmic significance. For example, the first column of the second page is headed shōgatsu shō, which marks this first month (shōgatsu 正月) as a short (shō 小) 29-day month. Strung out beneath it are multiple referents for the $1^{\text {st }}$ month: hi no e tora 丙寅, i suku 胃宿 and chō suku 張宿. In the columns for the first, second and third days of the month are respectively the following designations of significance: $\operatorname{mi}(z u)$ no to no $u$

6 The five other kami are Saigyō (Saikei), Saiha, Saisetsu, Oban and Hyōhi, who occupy the eastern, southern, south-western, north-eastern, north-western quarters respectively for the duration of Bunkyū 4. 
みのとのう, nozoku のぞく, ki no e tatsu きのえたつ, mitsu みつ, ki no to no $m i$ このとのみ and taira たいら.

Knowledge of the sexegenary cycle, the five phases of matter and yin yang theory, as well as of the stars and the planets, is essential to decoding the spatial and temporal information on the opening pages of this Bunkyu 4 calendar. In what follows, I offer a preliminary decoding before examining the sources of specialist knowledge available to the common man or woman in Tokugawa Japan. I then return to consider the question of the calendar and religious practice.

\section{Tokugawa space and Tokugawa time}

\section{Space}

The benevolent kami Toshitokujin brings good fortune throughout the four seasons but especially at New Year. Anyone wishing to marry, give birth, embark on travel or build - at any time of the year - would be well advised to identify Toshitokujin's direction and act facing it. The year 1864 was one of those in the sexegenary cycle that corresponded to the elder brother of wood ( $h i$ no $e$ 丙) phase; in such years Toshitokujin resides in the direction of the monkey, between the directions of the tiger and rabbit. Only the malevolence of the kami Konjin can undermine the auspiciousness of Toshitokujin. So, for example, as Konjin passes in 1864 through the direction of the monkey, he saps Toshitokujin's benign powers. As for the kami Konjin himself, he is the manifestation of the spirit of Venus, which is the planet of metal or kinsei 金星. Konjin is, thus, the kami of metal and so partakes precisely of metal's cold and unforgiving quality. So malevolent is Konjin that those who offend him by performing (unspecified) actions facing the directions in which he resides will forfeit their own lives and those of six family members besides. Taisai, the first of the eight kami who line up atop the calendar's first page, is the spirit of Jupiter or mokusei 木星 which is why, of course, the caption beneath his name carries not only an encouragement but a warning as well: 'Facing this [northern] direction all will be auspicious, but the cutting of wood is taboo.' Jupiter is, after all, the planet of wood - and woodcutting will cause him offence. Daishōgun, the third kami, is a second manifestation of Venus. This kami is cold, metallic and only marginally less malevolent than Konjin. The caption cautions of a taboo in the western quarter for the three years during which Daishōgun is resident there. Daion, for her part, is the spirit of Saturn, 
dosei 土星 or the planet of earth, and the princess of Daisai. She is, on the whole, benevolent, especially towards those engaged in academic pursuits, but woe betide the pregnant mother who gives birth facing Daion in the north west.

In brief, all of the kami that shape the first page of the typical Tokugawa calendar, with the exception of Toshitokujin and Dokujin, are stellar, planetary kami. They are endowed with numinous powers to bestow good fortune, or alternatively to wreak havoc, upon humankind. What determines the one, as opposed to the other, is human observance of taboos in the practice of everyday life relating to specific directions. Those directions are, in their turn, determined partly by the movement of the stars and planets through the heavens and partly by calculations of space and time according to the sexegenary cycle, the five phases of matter and yin yang theory.

\section{Time}

How then might we decode the significance of the calendar in its dominant temporal mode? The first column on the left hand side of Figure 1 offers a suitable entry point. Hi no e tora identifies this $1^{\text {st }}$ month as the third in the sexegenary cycle, which the calendar applies to years and days, as well as to months. It is that month when the elder brother of the fire phase of matter ( $h i$ no e), which is the third of the ten heavenly stems (jikkan), coincides with the tiger (tora) of the twelve earthly branches (jünishi). I suku encodes a further layer of cosmic meaning. The suku, rendered into English by Richard Smith as 'lunar lodges', identify lunar patterns projected onto the zodiac. ${ }^{7}$ The zodiac, that band of fixed stars marking the apparent course of the sun about the earth, comprises four lunar lodges - east, north, west and south; each 'lodge' is then subdivided into seven, giving twenty-eight. The first month of Bunkyū 4 (1864) coincides with the western $i$ lodge, the $17^{\text {th }}$ of twenty-eight in total, a month inauspicious for marriage and building work, but not for the cutting of cloth. This cosmic system of lunar lodges was also mapped on to days of the month. The $1^{\text {st }}$ day of this month aligns with the $26^{\text {th }}$ cho lodge. The sowing of seeds, and indeed, all sericulture-related activities are taboo on chō days.

The deeper complexities of time in Tokugawa Japan are suggested by the most cursory examination of the columns for the days of the month.

7 Richard Smith, Fortune Tellers and Philosophers: Divination in Traditional Chinese Society, Oxford: Westview Press, 1992, p. 63. 
Taking, by way of example, the first three days only, each is first marked according to the sexagenary cycle, composed of the ten heavenly stems and the twelve earthly branches. Beneath the $1^{\text {st }}, 2^{\text {nd }}$ and $3^{\text {rd }}$ days of the month are designated nozoku, mitsu and taira respectively. These refer to the $2^{\text {nd }}, 3^{\text {rd }}$ and $4^{\text {th }}$ phases respectively of the cycle of twelve 'stellar coincidences' known as jünichoku 十二直. Tokugawa astronomers calculated these by plotting the movements of the three stars that make up the handle of the Big Dipper as they rotate about the Pole star, before mapping them on to the passage of days. What is significant is that each stellar coincidence embodies its own particular brand of fortune and misfortune. Nozoku days, for example, are great for banishing evil influences of all sorts, and so bathing and cleaning are highly recommended; marriage, though, and travelling are best avoided. The mitsu phase of the cycle identifies a day overflowing with good fortune for the most part, though taking medicines is ill-advised. Taira days are blessed, and marriage, travel and wall-painting may all be undertaken with confidence, but the sowing of seeds is inauspicious.

\section{Calendars and their almanac commentaries}

Until the Tokugawa period, knowledge of yin yang, the five phases of matter and the sexegenary cycle - not to mention the multiple lunar and stellar systems which they generated - seems to have remained the exclusive preserve of the imperial court in Kyoto and its yin yang specialists (onmyōji 陰陽師), notably the Tsuchimikado 土御門 family. From the late $17^{\text {th }}$ through the early $18^{\text {th }}$ centuries, however, this knowledge began to percolate to a much wider audience, until by the end of the period it constituted early modern Japanese 'common sense'. The calendar, and the almanac commentaries on the calendar, were the principle carriers of this common sense. They were responsible for ensuring that it and its various prescriptions were reproduced the length and breadth of Japan. It may be that the compilation and subsequent publication of the Wakan sansai zue 和漢三才図絵 in 1712 was a pivotal moment. The Wakan sansai zue was Japan's first ever encyclopedia, its 105 volumes constituting a stupendous feat of editing, synthesis and learning by Terajima Ryōan 寺島良安 (dates unknown). Terajima, who drew heavily on the Ming Chinese text Wakan sansai, was official physician to Osaka castle and renowned in the Kansai area as a polymath. The second of his volumes on astronomy, the fourth on time and the fifth on fortune telling, are a treasure-trove of specialist knowledge vital to the 
decoding of the Tokugawa calendar's secrets. ${ }^{8}$ Here in Terajima's text is to be found knowledge, in textual and pictorial form, of Konjin, Taisai and Daishōgun. Detailed expositions of the logic of the twelve stellar coincidences, the twenty-eight lunar lodges and, of course, yin yang, the five phases and the sexegenary cycle, are all to be found in the pages of the Wakan sansai zue. ${ }^{9}$ It would, of course, have taken a well-to-do, leisured man or woman of quite considerable learning to digest the calendrical wisdom of Terajima's encyclopedia. It comprises, after all, over a hundred substantial volumes divided into eighty-one books; it is written for the most part in kanbun 漢文, and is replete with quotations from Chinese sources. It is not known how widely the Wakan sansai zue was distributed, but the compiler's insertion of Japanese readings of Chinese terminology and his peppering the text with illustrations probably helped to ensure a wider circulation than would otherwise have been possible.

Several generations before the end of the Tokugawa period, however, single-volume compendia of knowledge, known generically as zassho 雑書 ('books of assorted knowledge') had begun to proliferate. These zassho were to all intents and purposes almanacs, and I shall refer to them as such. They seem to have drawn much of their information and evidently most of their illustrations directly from Terajima's work Wakan sansai zue. By the $19^{\text {th }}$ century, almanacs were proliferating to such an extent that it is estimated pretty well every household in urban and rural Japan had access to one. The almanacs brimmed with information on medicine, child-rearing, agriculture, geography, history and ethics, but in terms both of their structure and of the space they devote to the calendar, it is evident that calendrical commentary was the true purpose of the genre. $^{10}$

The Tenpō shinsen eitai daizassho manreki taisei 天保永代大雑書萬暦大成 produced in the 1840s is typical of the sort of single-volume almanac that would have been accessible to the reader of

8 Heibonsha has published the Wakan sanzai zue in 10 volumes: Terajima Ryoan, Wakan sansai zue (Shimada Isao et al. comp.), Heibonsha, 1985-1991.

9 For the $i$ and chō stations, see Terajima, Wakan sansai zue 1, pp. 126-8 and pp. 151-2 respectively. For the 12 choku see, ibid., pp. 356-7.

10 On the riches of the Tokugawa almanac, see Yokoyama Toshio, 'Daizassho kō: tashin sekai no baikai,' Jinbun gakuhō, 86 (2002). 
our 1864 calendar. ${ }^{11}$ Unlike the Wakan sansai zue, this Eitai daizassho is written in Japanese, with all Sino-Japanese characters glossed with furigana. It is abundantly illustrated, with many of its illustrations replicating those used by Terajima in his earlier work. The almanac, moreover, compacts all its information between the covers of a single volume of about 300 pages. The $10^{\text {th }}$ section of the Eitai daizassho is entitled Koyomi no chūshaku 暦の注釈 ('Calendrical commentary'), and it is herein that the keys for decoding the calendrical secrets are revealed. Section 13 (see Figure 2) yields the significance of the nyoi hojju. Its three jewels are, after all, 'three celestial maidens of the sun, the moon and the stars, who bring good fortune as they move through the heavens'. All who set eyes on the jewels are blessed with good fortune. Taisai, Daishoggun and Daion and their five stellar companions appear on these pages in corporeal guise. They are not, the reader learns, the eight royal offspring from the coupling of Susano'o and Inada hime, as legend would have it. This is fabrication 'for, when one consults calendrical sources, it is clear they are the spirits of the five planets [Jupiter, Mars, Venus, Mercury and Saturn]' (Section 15). Here is to be found confirmation, too, that Taisai resides in the northern quarter. Dire warnings against woodcutting, and some helpful elaboration too, are provided: it is the twelve positions which Taisai (Jupiter) occupies in his twelve-year circuit of the heavens that make sense of the twelve directions he occupies. So, in years of the rat, Taisai resides in the rat quarter; in ox years, the ox quarter and so forth (Section 15).

Unspecified yin yang sources are adduced to prove the malevolence of Daishōgun. Here, he is styled a 'military deity' charged with protecting the realm. His wanderings are plotted in caption and diagram, with greater precision than the calendar allowed. The reader is reminded that Daishōgun resides in any one quarter for a full three years before moving on, and this of course explains the three-year taboo cited in the calendar. Here are specific warnings against building, moving house or marrying in the 'deeply to be feared' direction of Daishōgun (Section 15). The Eitai daizassho again cites unnamed yin yang texts to identify the unsettled period of eighteen days (known as doyō) prior to spring, summer, autumn and winter respectively: these are phases when Daishoggun departs on

11 I have consulted the British Library version (BL Oriental Reading room 1600 a8). I am very grateful to Professor Yokoyama Toshio of Kyoto University for pointing me in the direction of this invaluable source and to Hamish Todd of the British Library for giving me access to it. 
seasonal excursions from his otherwise fixed abode. The almanac reader is advised that, at such times, only the eastern direction is subject to Taisai taboo, and is encouraged to take advantage of this freedom to act (Section 17). It is also within the pages of the almanac that are to be found detailed articulations of the benevolence of Toshitokujin and the malevolence of Konjin, which can anyway perhaps be inferred from their portraits (Section 16; see also Figures 3 and 4).

Explanations in clear, concise, furigana-glossed Japanese are furnished here for any wishing to delve into the logic of the twelve stellar coincidences (Section 24, 114), the twenty-eight lunar lodges (Section 29) and, of course, the yin yang, five-phase thinking that underpins them both (Sections 89, 90, 108, 109).

\section{Tokugawa religious practice}

I proposed at the outset that calendars might serve as a method of approaching the individual practice of Tokugawa religion. I contended that they offer insights into popular religious practice in the early modern period, and I should clarify what I mean here by 'religious practice'. I mean to imply specific actions motivated 1) by dispositions of awe before certain stellar and planetary kami; especially, though, by dispositions of fear of unimaginable punishments, and 2) by a dread of disturbing, through a lack of knowledge or wisdom, the cosmic order embodied, partly at least, by these stellar kami. Religious practice is, in this sense, then, the negotiation of a complex network of spatial and temporal boundaries. Tokugawa religious practice becomes as much a matter of what you do not, or cannot, do, for fear of taboo, as what you are bidden to do in order to avoid taboo and incur beneficence.

The question of the extent to which the common man or woman in the $1840 \mathrm{~s}, 1850 \mathrm{~s}$ and $1860 \mathrm{~s}$, the period that is of greatest concern to me, observed these taboos must be tackled if the argument proposed here, namely that calendars offer a vital insight into Tokugawa religious practice, is to be persuasive. The present paper is preliminary and a full exploration of the question of observance I must postpone to a subsequent article. Here it must suffice to recall that the calendar achieved near saturation in rural and urban Tokugawa Japan. The annual printing of 4.5 million calendars and their distribution among a population of some 30 million suggest that most families in Japan owned a calendar; most families, we know, had access, too, to an almanac. Until more detailed research demonstrates the contrary, we are entitled to presume that calendars and almanacs did, indeed, play a vital part in 
determining religious practice. Here, I conclude by offering some brief observations on just two of many popular cults in Tokugawa Japan that were promoted by the calendar, and which have so far not occupied a prominent place in studies of Tokugawa religion and its practice: Daishōgun and Kōshin 庚申.

\section{Two Tokugawa cults}

\section{Daishōgun}

Of the cult of Daishōgun, the kami of the planet Venus, who was hardly less malevolent than the other kami of Venus, Konjin, there is material evidence over a wide swathe of Japan. The Daishōgun hachi 大将軍八 shrine in Kyoto, which dates from the $8^{\text {th }}$ century, and was one of four built to protect the imperial capital, is the best preserved example of a shrine, but there survive to this day Daishōgun shrines across Japan from Fukuoka in the south west through Hyogo and Fukui in central Japan to Iwate in the north. The relationship between the calendar and the proliferation of the cult is a complex one, which demands further exploration. But it would appear that the calendar helped render countrywide a phenomenon that was, prior to the Tokugawa period, local. For example, the Kyoto Daishōgun hachi shrine keeps a Tokugawa period register, known as the kakiagecho 書き上げ帳, which lists a network of Daishōgun shrines in the Kansai area, subordinate to it; all of these were Tokugawa creations. None of these now survives, however, since they were eliminated in the iconoclastic fury of the Meiji Restoration of 1868. Daion, Daisai and Saikei appear not to have developed as cults independent of the kami Daishōgun, but the Daishōgun hachi shrine accommodates statues of these and the other kami, and this may have been the model for Daishōgun shrines across Japan. What is needed is local research to determine the precise nature of religious practice before the kami Daishōgun in its multiple manifestations. What offerings were presented, on what occasions and in what manner, for the propitiation of Daishōgun? The almanac offers no insights at all. Its unique concern is to plot Daishōgun's movements in order that mere mortals might avoid his devastating wrath.

\section{Kōshin}

The cult of Kōshin is one which, apart from anything else, exhibits the immensely creative dimension of Japanese religious culture. Kōshin denotes that phase in the sexegenary cycle when the older brother of 
metal (kanoe, a character which, in its Chinese reading, is also read as $k \bar{o}$ 庚) coincides with the metal of the monkey (saru, also read as shin 申; the combination of the two gives Köshin). This metallic coincidence was the herald of dramatic and inauspicious change in the community, and so demanded special observances. In China, Köshin days were taboo but, in Tokugawa Japan, this sexegenary coincidence was apotheosised as the kami Kōshin. Kōshin became the focus of widespread popular cult. On Kōshin days, early modern Japanese worshipped either the indigenous kami Sarutahiko 猿田彦or the Buddhist deity Shōmen kongō 青面金剛 (the blue faced Vajrapani), but the almanacs informed their readers that both Sarutahiko and Shōmen kongō were none other than Buddhist and Shinto manifestations of the kami Kōshin. In worshipping Sarutahiko or Shōmen Kongō, they worshipped none other than Kōshin. Evidence of the cult is to be found across Japan in sites known as Kōshintō 庚申塔. Sometimes they were a simple vertically-set stone engraved with the characters Kōshin. More typically they displayed an image of Shōmen kongō, beneath whom are the three monkeys identified with Sarutahiko. Late Tokugawa almanacs offer an interesting critique of the Daoist theory of Kōshin. Chinese Daoist theory held that three worms inhabited the head, stomach and legs, and that these left the body during sleep on Kōshin days; they ascended to heaven and reported to the deity of the pole star, Tentei 天帝, on evil deeds done. Their purpose was to call down the wrath of heaven on the person responsible. The Tokugawa almanac insists that the reality was quite different. The human body was not inhabited by worms at all: 'This is no more than a parable to get men and women to stay awake all night and abstain from sexual intercourse for, on these nights, it is bodily fluids, but especially semen, which are indeed polluting.' (Section 41). ${ }^{12}$

\section{Conclusion}

In order to pursue the possibilities of the calendrical approach to a study of the religious practice in Japan - it is this which Janine Sawada identifies as sorely lacking - several issues demand further attention. First of all, it is vital to explore the extent to which calendars not only entertained the common man or woman but informed their practice. What evidence is there that Japanese actually took their calendars seriously and

12 For a study of the Daoist origins of the Kōshin cult, see Livia Kohn, 'Kōshin: a Taoist cult in Japan (Part 2 Historical development),' Japanese Religions, 20, 1. 
74 Inside Tokugawa religion: stars, planets and the calendar-as-method

consulted them before marriage, before departing on travels and before undertaking building works or agriculture, and having consulted them, acted in ways the calendar prescribed? Secondly, we need to explore the different varieties of calendar that proliferated in early modern Japan. There were, despite government attempts at regulation, regional variations, and divergences in form and style; different calendars gave different weight to matters astrological and matters astronomical. There is a need, too, to explore deeper the dynamics of the proliferation of the calendar and the almanac. Why did they proliferate so widely and so rapidly in early modern Japan; what role was played here by the state, and what was the role of private enterprise? Perhaps the most important implication of the calendar for our understanding of Tokugawa religion is the light which it sheds on the prevalence of yin yang, the five phases of matter and the sexegenary cycle. It would seem beyond doubt that this wisdom, disseminated by the calendar, played a determining role in Tokugawa religious practice that until now has gone entirely without recognition.

Culture and Cosmos 
John Breen 75

Figure 1 Bunkyū 4 (1864) calendar, published in Kyoto by the Furuya family of printers. http://www.ndl.go.jp/koyomi/rekishi/img/0586-15lar.jpg

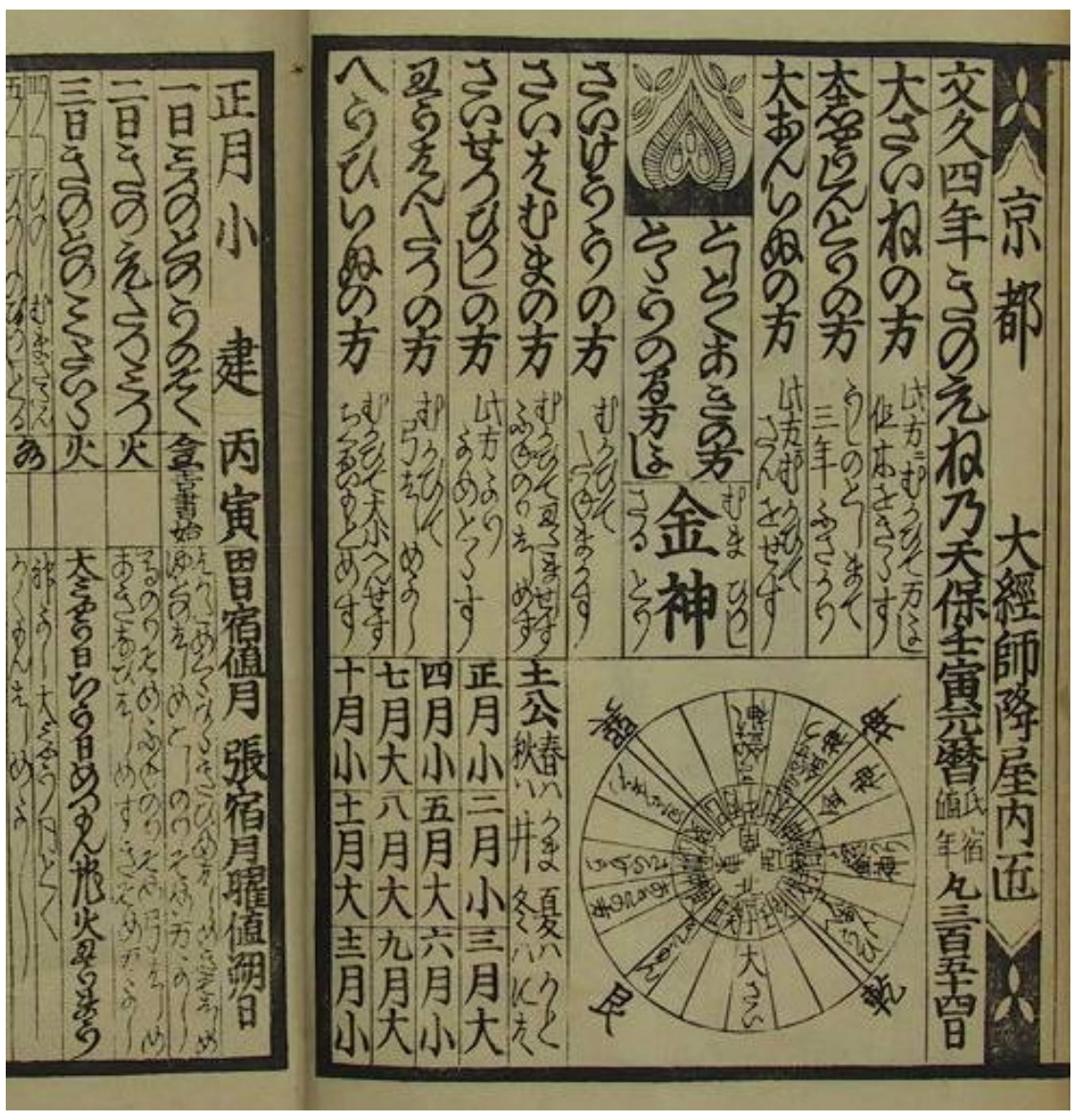


76 Inside Tokugawa religion: stars, planets and the calendar-as-method

Figure 2 The nyoi hōju jewels. From a reprint of the Tenpō shinsen eitai daizassho manreki taisei, 1842.

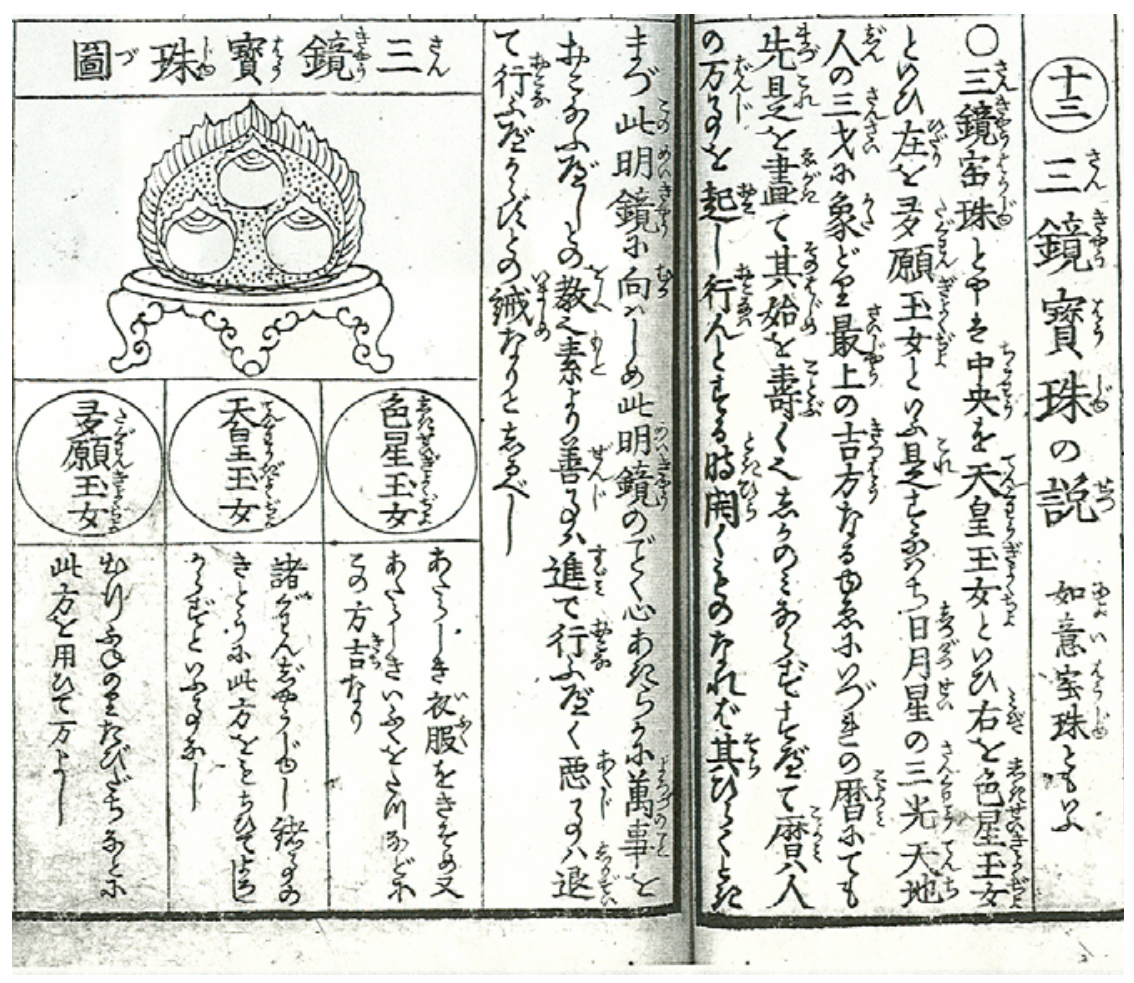

Culture and Cosmos 
Figure 3 Toshitokujin, as depicted in a reprint of the Tenpō shinsen eitai daizassho manreki taisei, 1842.

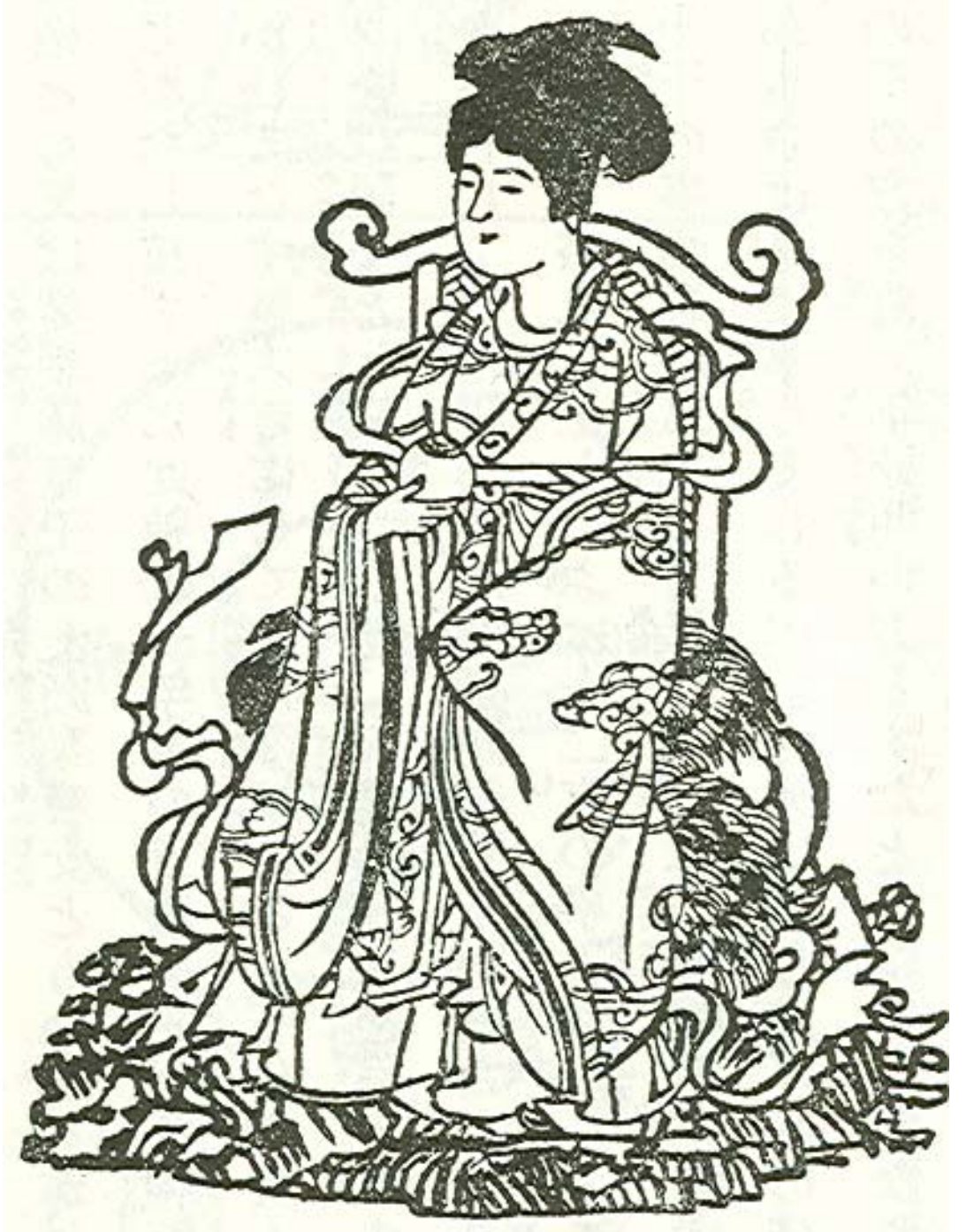

Culture and Cosmos 
78 Inside Tokugawa religion: stars, planets and the calendar-as-method

Figure 4 Konjin, the kami of Venus, as depicted in the Tenpō shinsen eitai daizassho manreki taisei, 1842.

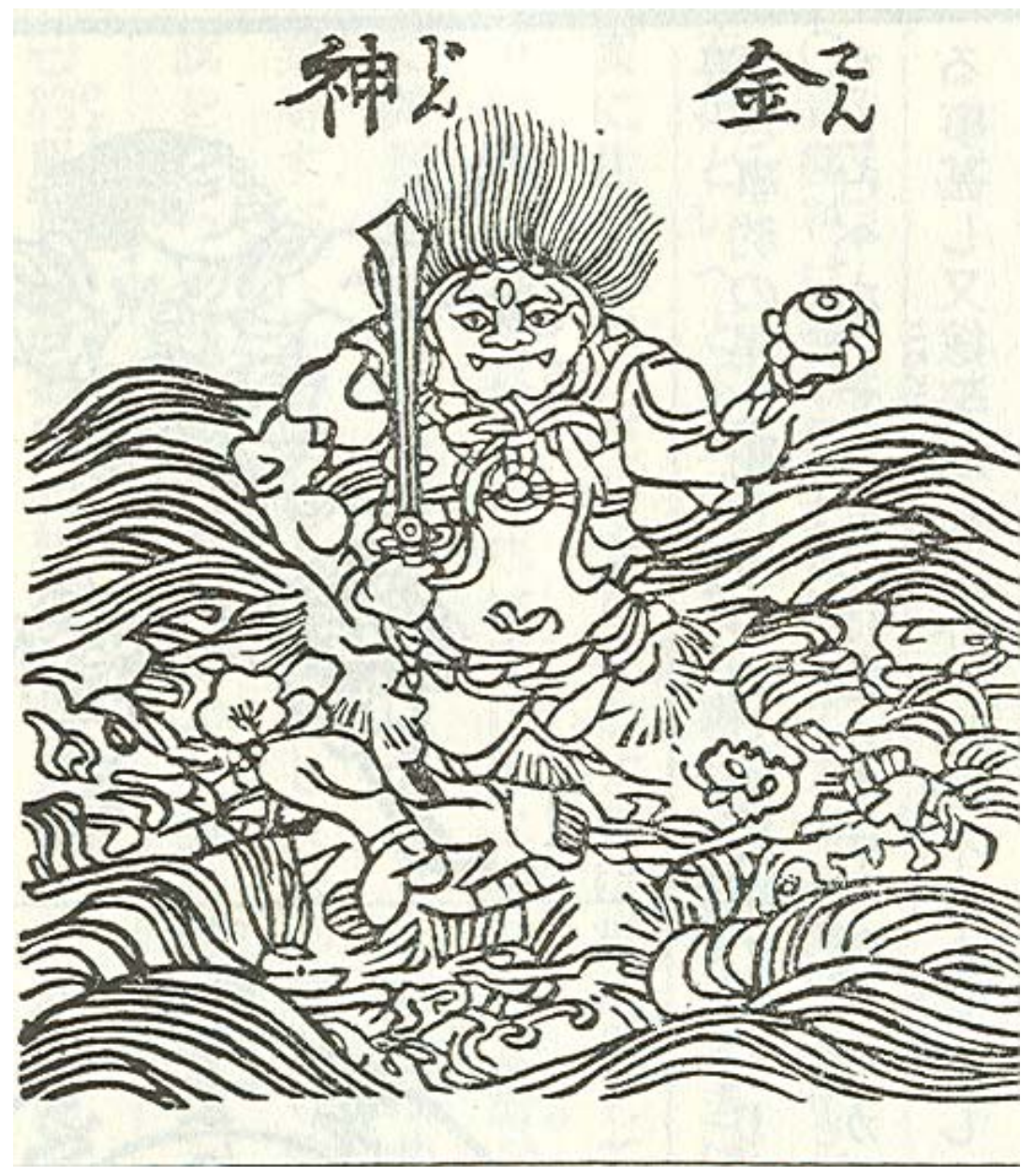

Culture and Cosmos 